\title{
POLA SEBARAN PLANKTON SECARA HORIZONTAL DI PERAIRAN DESA OHOILILIR, KABUPATEN MALUKU TENGGARA
}

\section{Plankton Distribution Pattern Horizontally In Ohoililir Water, Southeast Maluku Regency}

\author{
Fabian N.J. Souisa ${ }^{*}$, Erna Almohdar ${ }^{2}$ \\ ${ }^{1}$ Jurusan Teknologi Hasil Perikanan, Poltek Tual, 39411, Indonesia. \\ ${ }^{2}$ Jurusan Teknologi Hasil Perikanan, Poltek Tual, 39411, Indonesia. \\ *Korespondensi: fnjsouisa@gmail.com
}

\begin{abstract}
ABSTRAK
Plankton dibagi menjadi dua golongan yaitu fitoplankton dan zooplankton. Fitoplankton adalah tumbuhan mikroskopis yang hidup melayang-layang di permukaan air, sedangkan zooplankton herbivora atau karnivora yang bersifat planktonik. Tujuan untuk mengetahui pola sebaran horizontal plankton di perairan Desa Ohoililir, Kabupaten Maluku Tengga. Pengambilan sampel plankton pada Oktober 2015 dengan menggunakan plankton net yang mempunyai ukuran mata jaring $80 \mu \mathrm{m}$ pada 4 stasiun. Kelimpahan total plankton berkisar antara 1,785,000-3,015,000 sel/m3 dan zooplankton kelas Crustacea mendominansi perairan tersebut. Spesies dominan di perairan ini dan selalu ada di setiap stasiun adalah spesies Branchionus angularis dengan kelimpahan tertinggi (49,000 sel/m3). Kelimpahan plankton tertinggi terjadi di stasiun ke 2 dan terendah di stasiun 4. Pola sebaran horizontal dengan konsentrasi tertinggi terdapat di stasiun ke-2 dengan nilai kelimpahan lebih dari $30.000 \mathrm{sel} / \mathrm{m} 3$.
\end{abstract}

Kata kunci: Sebaran, Plankton, Maluku Tenggara

\begin{abstract}
Plankton is divided into two classes phytoplankton and zooplankton, where phytoplankton is microscopic plants that buoyant and float in the upper part of the ocean, whereas herbivor and carnivore zooplankton have more planktonic characteristic. This research aimed to figure plankton distribution pattern horizontally in Ohoililir water, Southeast Maluku Regency. Collecting data conducted on October, 2015 by using plankton net with $80 \mu \mathrm{m}$ mesh size on four stations. Total Profusion plankton were around $1,785,000-3,015,000$ cell/m3 which the most dominant zooplankton found were from crustacean class and Branchionusangularis genus as high as 49,000 cell/m3. The highest profusion was on second station and the lowest was on fourth station. Highest distribution pattern horizontally was on second station with profusion value more than 30.000 cell/m3.
\end{abstract}

Key words: Distribution, Plankton, Southeast Maluku 


\section{PENDAHULUAN}

Desa Ohoililir merupakan daerah strategis bagi masyarakat, dimana perairan ini dibagi dalam 4 zona. Pertama adalah zona pemukiman penduduk, pada zona ini masyarakat bebas melakukan aktifitasnya baik penangkapan, pariwisata dan lainnya. Kedua adalah zona penangkapan dimana pada zona ini masyarakat bebas melakukan kegiatan penangkapan. Ketiga adalah zona usaha, pada zona ini terdapat usaha budidaya rumput laut. Keempat zona wisata, dimana pada zona ini terdapat kawasan wisata yang menyediakan panorama keindahan bagi pengunjung dan terdapat pasir panjang yang luas membentang. Adanya kegiatan yang berbeda pada masing-masing zona di perairan ini menyebabkan perbedaan kesuburan perairan pada masingmasing zona tersebut. Kesuburan perairan dapat diketahui salah satunya dengan mengukur sebaran plankton.

Plankton dibagi menjadi dua golongan yaitu fitoplankton dan zooplankton. Fitoplankton adalah tumbuhan mikroskopis yang hidup melayang-layang di permukaan air, sedangkan zooplankton pemakan herbivora atau karnivora yang bersifat planktonik. Fitoplankton bersifat autotrof dan menjadi produsen primer perairan, sedangkan zooplankton merupakan konsumen tingkat pertama yang langsung memangsa fitoplankton. Dalam rantai makanan selanjutnya zooplankton menjadi sumber makanan organisme yang lebih tinggi tingkatannya. Perubahan fungsi perairan sering diakibatkan perubahan struktur dan nilai kuantitatif zooplankton. Perubahan ini dapat disebabkan faktor fisika, kimia maupun aktivitas manusia. Hal ini tergantung dari kondisi beberapa faktor oseanografi pada perairan tersebut, yang meliputi kedalaman, kecerahan, kecepatan dan arah arus, suhu, salintas, oksigen terlarut dan nutrien. Berbagai jenis ikan pe!agis kecil, pelagis besar dan demersal serta biota air lainnya sangat melimpah dan menjadi sasaran tangkapan nelayan. Kelimpahan berbagai jenis ikan pelagis kecil, terutama ikan pemakan plankton (planktivor), secara langsung sangat dipengaruhi oleh pertumbuhan dan kerapatan plankton menjadi makanan utamanya (Hickman et al. 2009). Adapun yang menjadi tujuan dari penelitian ini adalah untuk mengetahui sebaran plankton secara horizontal di perairan Desa Ohoililir Kabupaten Maluku Tenggara.

\section{METODE PENELITIAN}

\section{Waktu dan Tempat}

Penelitian dilakukan di perairan Desa Ohoililir Kabupaten Maluku Tenggara selama 1 (satu) bulan yakni pada bulan Oktober 2015. Analisis sampel dilakukan di Laboratorium Hama dan Penyakit, Politeknik Perikanan Negeri Tual. Pengambilan sampel plankton dilakukan pada empat lokasi yaitu: lokasi pemukiman penduduk, lokasi penangkapan, lokasi usaha budidaya dan, lokasi wisata. Lokasi penelitian dapat dilihat pada Gambar 1.

\section{Metode Pengambilan Sampel}

Metode pengumpulan data pada penelitian ini menggunakan metode purposive random sampling pada daerah yang telah ditentukan. Plankton net yang digunakan mempunyai ukuran mata jaring 80 $\mu \mathrm{m}$, diameter mulut jaring $0,31 \mathrm{~m}$ pada 4 stasiun. Pengambilan sampel menggunakan satu jenis jaring yang ditarik dari dasar menuju permukaan perairan (horizontal). Identifikasi plankton secara deskripsi meng-gunakan buku kunci identifikasi plankton dari Hutabarat dan Evans (1986), Needham, (1962), Smith (1952), dan Wells (1961). Sampel plankton diberi pengawet formalin $4 \%$ dan disimpan dalam botol selanjutnya diberi label dan dibawa ke laboratorium untuk diidentifikasi. Di laboratorium pada saat pengamatan, tiap botol sampel plankton dikocok agar merata, kemudian diambil sebanyak satu mililiter dan diletakkan pada gelas sadwick rafter, selanjutnya diamati pada mikroskop dengan pembesaran 40x. Tiap sampel plankton diidentifikasi hingga tingkat genus. 


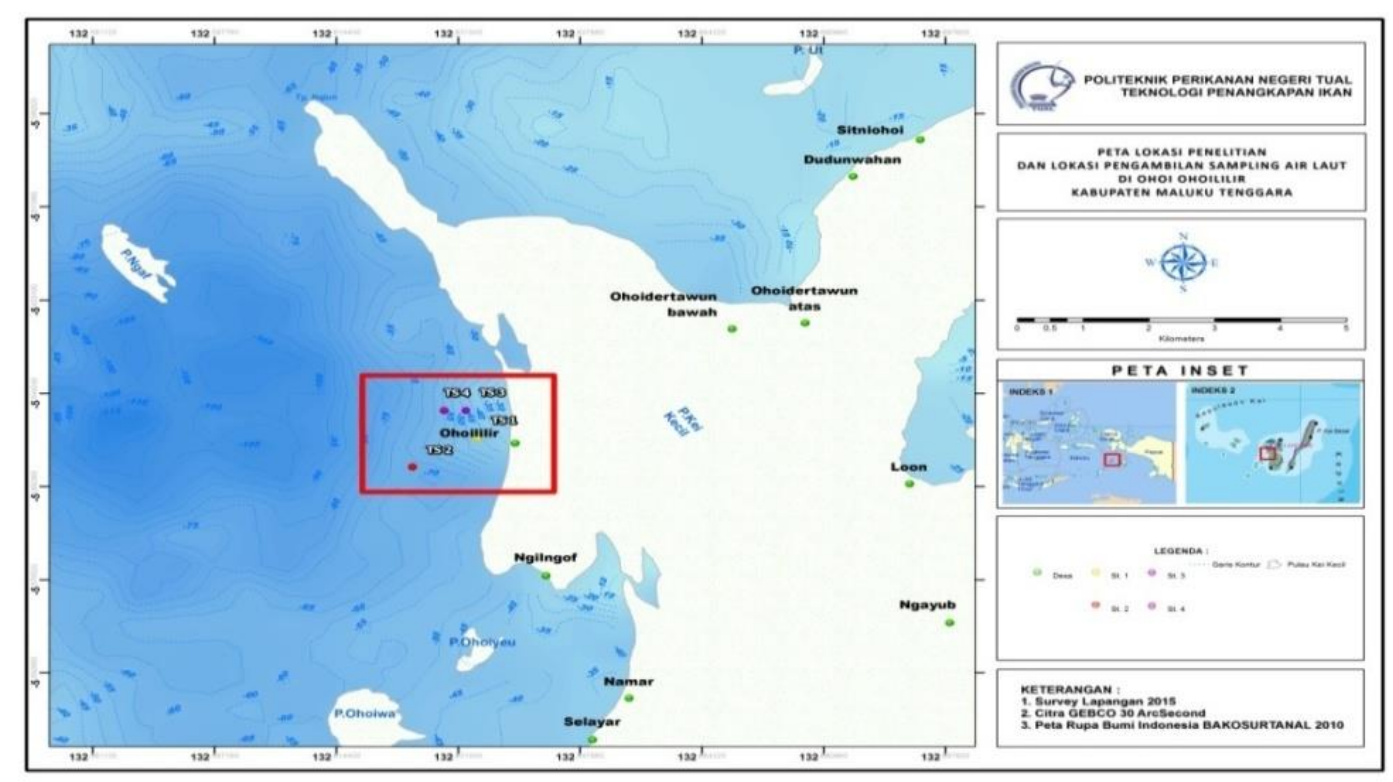

Gambar 1. Peta Lokasi penelitian di Perairan Desa Ohoililir.

Kelimpahan plankton dihitung dengan formula berikut.

$$
\mathrm{N}=\mathrm{n} \text { i } x(\mathrm{Vr} / \mathrm{Vo}) \times(1 / \mathrm{Vs})
$$

Keterangan:

$\mathrm{N}$ = Jumlah individu plankton genus (i/m3)

$\mathrm{Vr}=$ Volume air tersaring $(\mathrm{ml})$

$\mathrm{Vo}=$ Volume yang diamati $(\mathrm{ml})$

$\mathrm{Vs}=$ Volume air yang disaring (m3)

$\mathrm{Ni}=$ Jumlah plankton genus $\mathrm{i}$ pada volume air yang diamati (individu).

Beberapa indeks biotis dihitung untuk mengetahui kondisi komunitas plankton antar stasiun penelitian. Indeks yang dihitung adalah "Shannon Index of Diversity" (Odum, 1994), untuk mengetahui keanekaragaman spesies $(\mathrm{H})$. Penghitungan indeks dilakukan dengan formula berikut:

Dimana :

$$
\mathrm{H}=-\Sigma(\mathrm{ni} / \mathrm{N}) \ln (\mathrm{ni} / \mathrm{N})
$$

$\mathrm{H}=$ Indeks Keanekaragaman

$\mathrm{Ni}=$ Jumlah Individu setiap spesies

$\mathrm{N}=$ Jumlah Individu Keseluruhan

Sedangkan untuk Indeks keseragaman/kemerataan, dihitung menggunakan "Evenness Index" (Odum, 1994), dengan persamaan :

$$
\begin{gathered}
E=H^{\prime} / H^{\prime} \max \\
H^{\prime} \max =\ln \mathrm{S}
\end{gathered}
$$

Dimana:

$$
\begin{array}{ll}
\mathrm{E} & =\text { Indeks Keanekaragaman } \\
\mathrm{H} ' \max & =\text { Keanekaragaman Maksimum } \\
\mathrm{S} & =\text { Jumlah seluruh spesies }
\end{array}
$$

\section{HASIL DAN PEMBAHASAN}

Berdasarkan hasil penelitian pada empat stasiun pengamatan maka pada stasiun ke dua yaitu lokasi penangkapan terdapat plankton tertinggi. Jumlah kelimpahan total plankton yaitu $3.015 .000 \mathrm{sel} / \mathrm{m}^{3}$ yang terdiri dari 10 jenis fitoplankton dan 10 jenis zooplankton. Dimana jumlah fitoplankton yang dominan adalah Nitzschia commulata $(566,67 \%)$. Untuk jenis zooplankton yang dominan yaitu Coscinodiscus $(3,296 \%)$. Selain itu jumlah plankton terendah terdapat pada stasiun 4 yaitu lokasi wisata dengan jumlah 2.190.000 sel $/ \mathrm{m}^{3}$ (Gambar 2).

Prinsip penyebaran plankton secara horizontal adalah ketidakmerataan atau ketidaksamaan. Pada suatu perairan biasanya terjadi ketidakmerataan penyeba-ran plankton. Umumnya penyebaran fitoplankton cenderung mempunyai penyebaran yang lebih merata dari pada penyebaran zooplankton. Kelimpahan zooplankton di suatu perairan lotik jauh lebih sedikit dibandingkan dengan fitoplankton. Barus (2002) menyatakan bahwa kecepatan arus terhadap zooplankton jauh lebih kuat dibandingkan pada fitoplankton. Oleh 
karena itu umumnya zooplankton banyak ditemukan pada perairan yang mempunyai kecepatan arus yang rendah.

Kelimpahan plankton pada masing masing zona di perairan Ohoililir tergolong tinggi, karena kelimpahan plankton berkisar $3.015 .000 \mathrm{sel} / \mathrm{m}^{3}$. Nilai keanekaragaman plankton pada zona penangkapan $(24,678)$, zona budidaya $(20,736)$ dan zona pariwisata $(20,07)$ sedangkan pada zona pemukiman penduduk keanekaragaman menurun $(2,697)$. Rendahnya nilai keanekaragaman plankton pada stasiun 1 diduga dipengaruhi oleh kondisi suhu perairan yang relatif tinggi berkisar antara $28^{\circ} \mathrm{C}$ sampai $30^{\circ} \mathrm{C}$ yang merupakan ambang batas atas suhu optimal bagi kehidupan plankton. Menurut Hardjosuwarno (1990) indeks keanekaragaman tergolong tinggi. Hal ini menunjukkan keanekaragaman $(\mathrm{H})$, kemerataan (J), dan dominansi (C) merupakan 3 hal yang saling berkaitan dan mempengaruhi, dimana jika indeks kemerataan yang tinggi akan meningkatkan nilai indeks keanekaragaman, dan jika dominansi antar spesies juga tinggi menunjukkan pada ekosistem tersebut ada jenis yang mendominasi, hal ini kemungkinan disebabkan tingginya tingkat keanekaragaman plankton pada ekosistem tersebut.

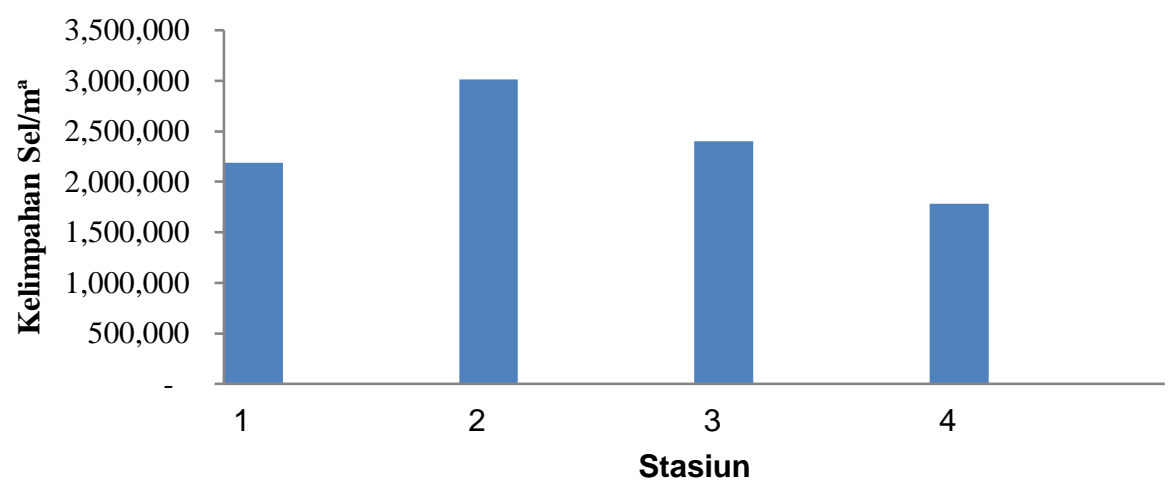

Gambar 2. Grafik Kelimpahan total pada setiap stasiun di Perairan Desa Ohoililir, Kabupaten Maluku Tenggara.

Seperti halnya pada plankton, nilai keanekaragaman zooplankton yang tinggi dipengaruhi oleh tingginya nilai indeks kemerataan zooplankton pada ekosistem tersebut, karena dengan nilai indeks kemerataan yang tinggi menunjukkan penyebaran zooplankton itu merata, sehingga keanekaragaman zooplankton menjadi tinggi, hal ini juga berpengaruh tehadap dominansi zooplankton di perairan menjadi tinggi karena akibat dari tingginya indeks keanekaragaman zooplankton. Adanya keterkaitan antara 3 hal tersebut menunjukkan bahwa kemerataan yang tinggi akan meningkatkan indeks keanekaragaman karena kemerataan yang tinggi menunjukkan kondisi ekosistem perairan yang stabil. Pola sebarannya kurang merata dengan indeks kemerataan berkisar antara 0,21-0,63. Koefisien variasinya sebesar $47,48 \%$. 


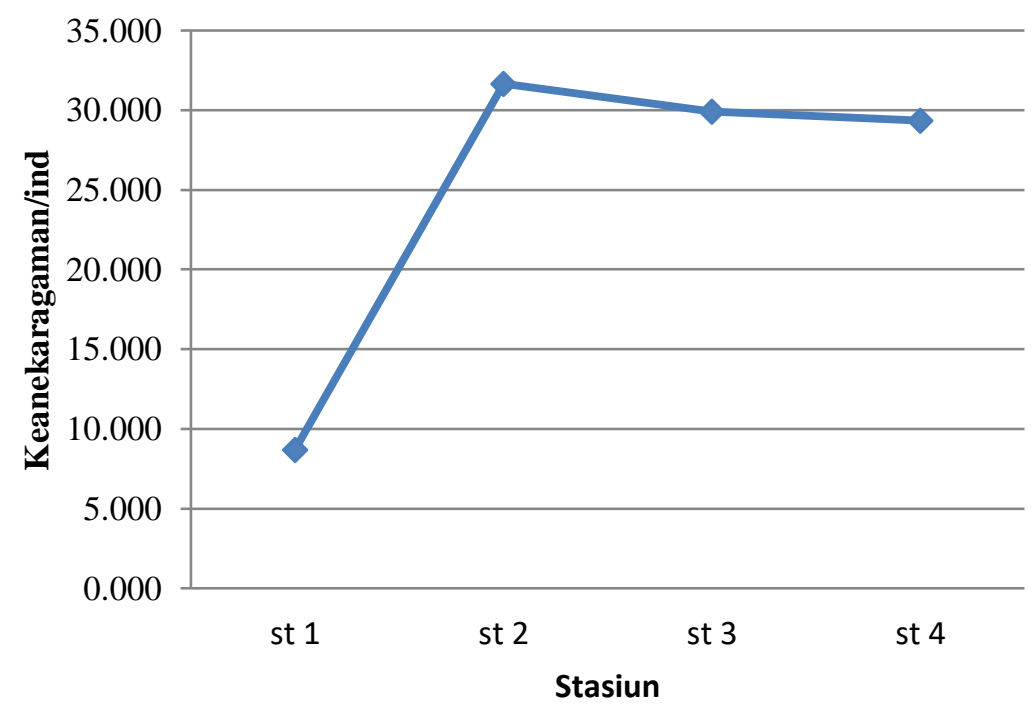

Gambar 3. Grafik Keanekaragaman total pada setiap stasiun di Perairan Desa Ohoililir, Kabupaten Maluku Tenggara.

Selain pengaruh dari faktor lingkungan berupa suhu perairan kemungkinan juga disebabkan karena adanya beberapa kendala pada waktu pengambilan sampel. Kendala yang dihadapi antara lain keterbatasan kemampuan alat-alat penelitian yang tidak memenuhi standar dalam pengambilan sampel. Sebaran plankton di perairan sekitar Pulau Ohoililir memperlihatkan perubahan musiman yang tidak jelas karena berada di daerah tropis, meskipun sangat dipengaruhi oleh musim barat dan timur namun yang paling berperan adalah perubahan ketersediaan bahan gizi atau unsur hara. Kondisi iklim dan cuaca memegang peranan yang penting terhadap dinamika populasi fitoplankton dan zooplankton (Eslinger 2001). Pada musim penghujan pertumbuhan populasi fitoplankton cenderung tinggi dan melimpah, menyebabkan biota air lainya, misalnya ikan, melakukan perkembangbiakan karena tersedia cukup makanan (Amundsen et al. 2008). Karena pada waktu pengambilan water sampel seringkali memutar saat berada di dalam air dan tutup water sampel seringkali sudah membuka sebelum mencapai kedalaman yang diinginkan. Hal ini kemungkinan menyebabkan sampel yang didapat tidak maksimal karea kemampuan alat-alat penelitian merupakan faktor utama dalam penelitian ini.

\section{KESIMPULAN}

Jumlah total kelimpahan plankton yaitu $3.015 .000 \mathrm{sel} / \mathrm{m}^{3}$ yang terdiri dari 10 jenis fitoplankton dan 10 jenis zooplankton. Dimana jumlah fitoplankton yang dominan adalah Nitzschia commulata (566,67\%). Untuk jenis zooplankton yang dominan yaitu Coscinodiscus (300 \%). Selain itu jumlah plankton terendah terdapat pada stasiun 4 yaitu lokasi wisata dengan jumlah $2.190 .000 \mathrm{sel} / \mathrm{m}^{3}$. Jumlah fitoplankton dominan adalah Nitzschia commulata $(300$ \%) dan zooplankton dominan yaitu Diacria Quadridentata (225\%), Pola sebarannya kurang merata dengan indeks kemerataan berkisar antara 0,21-0,63. Koefisien variasinya sebesar $47,48 \%$.

\section{DAFTAR PUSTAKA}

Amundsen PA at el., (2008). Seasonal and ontogenetic variations in resource use by two sympatric Arctic charr morphs. Environ Biol Fish. 83,45-55.

Barus, I.T.A. (2002). Pengantar Limnologi. Medan : Jurusan Biologi FMIPA USU.

Eslinger at el., (2001). Plankton dy nam ics: obser ved and modelled responses to physical conditions in Prince William 
Sound, Alaska. Fish. Oceanogr. 10 (suppl. 1), 81--96.

Hardjosuwarno, S. (1990). Dasar-Dasar Ekologi Tumbuhan. Yogyakarta : Fakultas Biologi UGM

Hickman A.A at el., (2009). Dist ribut ion and ch rom a tic ad apt at ion of phytoplankton within a shelf sea thermocline. Limnol. Oceanogr., 54(2), 525-536.

Hutabarat, S. dan S.M. Evans. (1986). Kunci Indentifikasi Zooplankton. Jakarta: Universitas Indonesia.
Needham, J.G and Paul R Needham. (1962). Fresh Water Biology. New York : Mc. Graw Hill Book Company.

Odum, E.P. 1994. Dasar-dasar ekologi (terjemahan). Gajah Mada University. Yogyakarta. 477hlm.

Smith G.M. (1950). The Fresh Water lgae of the United States. New York : Mc Graw Hill Book Company.

Wells T.A.G. (1961). Invertebrate Types. . New York : Mc. Graw Hill Book Company. 